\title{
Relationships of Heavy Metals in Water and Surface Sediment with Different Chemical Fractions in Lake Uluabat, Turkey
}

\author{
Saadet Hacısalihoğlu, Feza Karaer* \\ Department of Environmental Engineering, Faculty of Engineering, Uludag University, \\ Görükle, Bursa, Turkey
}

Received: 28 March 2016

Accepted: 26 April 2016

\begin{abstract}
Lake Uluabat is dependent on the RAMSAR Convention (the Convention on Wetlands of International Importance, especially as waterfowl habitat) which was accepted in Iran in 1971 as a member of Living Lakes network carried out by the Global Nature Fund. The lake is very important in terms of biodiversity. Relationships of physicochemical parameters of lakewater and sediment with chemical fractions of heavy metals (chrome and nickel) in lake sediments were investigated in Lake Uluabat in Bursa, Turkey. The concentrations of $\mathrm{Cr}$ and $\mathrm{Ni}$ forms (dissolved, particulate, total sediment, sediment fractions) and other water and sediment quality parameters were assessed monthly at 10 sampling points between August 2013 and July 2014. The results demonstrate that the concentrations of water and sediment quality parameters undergo monthly changes. The geoaccumulation (Igeo) index has been widely applied to the assessment of sediment contamination. According to this index, Lake Uluabat has moderately polluted sediment. $\mathrm{Cr}$ and Ni concentrations in sediment have been determined to be higher than the upper effect threshold according to international standards. Variations of the fractions of $\mathrm{Cr}$ and $\mathrm{Ni}$ bound to organic matter (F4), residual, and bound to Fe-oxide fractions (F5) were found to be the most dominant forms. Mostly, all forms of $\mathrm{Cr}$ and $\mathrm{Ni}$ were significantly and positively correlated with $\mathrm{pH}$, electrical conductivity, and suspended solids. The results revealed the importance and the need for strict control of point and non-point pollution loads for the preservation of Lake Uluabat's water and sediment quality.
\end{abstract}

Keywords: chemical fraction, Lake Uluabat, monitoring, pollution, water, sediment quality

\section{Introduction}

Expanding urban populations, traditional and developing technologies, and intensive agricultural production have greatly increased the amount of wastewater gene-

*e-mail: karaer@uludag.edu.tr rated in Turkey and many other countries. Levels of contaminants have also grown, including both organic (e.g., pesticides, petroleum hydrocarbons) and inorganic (e.g., metals) chemicals. The wastewater treatment capacity of the region has fallen far short of the level needed to meet the demand of multiple sectors. As a result, untreated and undertreated wastewater enters many streams and rivers, eventually finding its way to a lake [1]. Lake sediment 
is an essential part of the lake ecosystem due to its complex physical and chemical adsorption mechanisms [2]. Sediments accumulate contaminants and serve as sources of pollution to the ecosystems they are connected with. Pathogens, nutrients, metals, and organic chemicals tend to sorb onto both inorganic and organic materials that eventually settle in depositional areas. If the loading of these contaminants into the waterways is large enough, the sediments may accumulate excessive quantities of contaminants that directly and indirectly disrupt the ecosystem, causing significant contamination and loss of desirable species. Sediments have high storage capacity for contaminants. In the hydrological cycle, less than $0.1 \%$ of the metals are actually dissolved in the water, and more than $99.9 \%$ are stored in sediments [3]. It is extremely significant to analyze the heavy metal fractions and to find out the distribution in different fractions of heavy metals [4].

The aim of this research was:

1. To determine relationships of heavy metals (chrome and nickel) in water and surface sediment with different chemical fractions in Lake Uluabat sediment.

2. To determine the level of contamination in the region according to the chemical fractions.

3. To take precautions in order to reduce pollution.

4. To assess water and sediment quality.

In addition, the study will provide baseline data for future studies.

\section{Materials and Methods}

\section{Study Area}

Lake Uluabat is a stressed shallow lake in Turkey. It is located in the Marmara region in northwestern Turkey between $40^{\circ} 10^{\prime}$ North and $28^{\circ} 36^{\prime}$ East. The water surface of the lake is only $2 \mathrm{~m}$ above sea level. The mean value of water depth is $3 \mathrm{~m}$. In drought months the depth is $1.5 \mathrm{~m}$ and in rainy months it reaches a mean depth of $4 \mathrm{~m}$. The surface area of the lake is $161 \mathrm{~km}^{2}$ at maximum water level and $138 \mathrm{~km}^{2}$ at minimum level [5]. The major rivers feeding and draining the lake are Mustafakemalpaşa (MKP) Brook and Kocasu Brook, respectively. MKP Brook is located southwest of the lake and Kocasu Brook is located to the northwest. The location of Lake Uluabat and the sampling points are shown in Fig 1 .

\section{Sampling Methods and Analysis}

Water and sediment samples were collected from 10 different sampling points marked S1 S10 in Fig. 1. Samples were taken monthly between August 2013 July 2014. Water samples were taken from $0.5 \mathrm{~m}$ below the water surface using a Hydro-Bios brand standard sampler. Dissolved oxygen (DO), electrical conductivity (EC), temperature (T), and $\mathrm{pH}$ parameters of water were measured in-situ during the sampling process using a $\mathrm{HACH}$ brand Sension 156 device. Alkalinity, total phosphorus (TP), biochemical oxygen demand $\left(\mathrm{BOD}_{5}\right)$, chemical oxygen demand (COD), suspended solids (SS), and total nitrogen (TN) parameters were analyzed according to the American Public Health Association standard methods [6].

Water samples were filtered through milipore filter paper of preweighed $0.45 \mu \mathrm{m}$ pore size. The filtered water samples were acidified with $0.2 \%(\mathrm{v} / \mathrm{v})$ concentrated $\mathrm{HNO}_{3}$ and kept in glass bottles. The filter papers containing the suspended solids were air-dried and reweighed. They were digested with $4 / 1(\mathrm{v} / \mathrm{v}) \mathrm{HNO}_{3} / \mathrm{HCl}$ mixture using a microwave device. After cooling, digestions were diluted to $30 \mathrm{ml}$ with mili-Q water. Sediment samples were taken from the $5 \mathrm{~cm}$ layer of the surface sediment using an Ekman

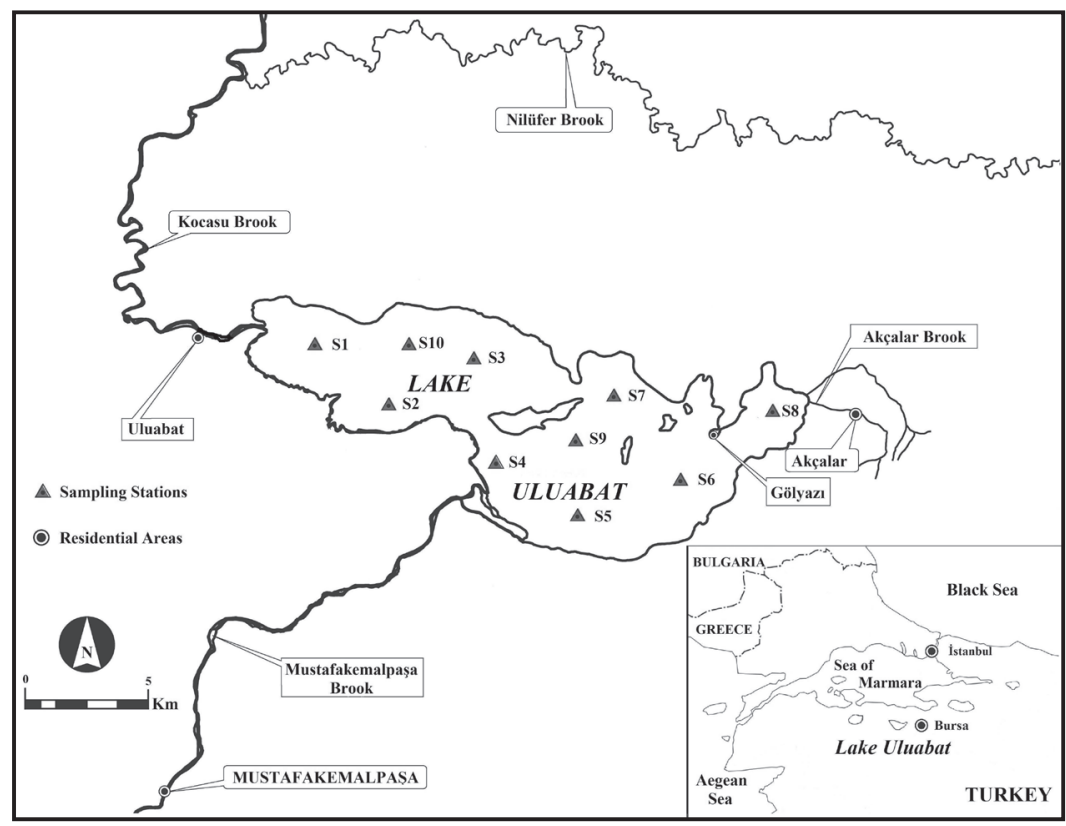

Fig. 1. Location of Lake Uluabat and sampling points. 
grab sampler. Sediment samples were air-dried and then sieved through a $0.2 \mathrm{~mm}$ mesh. $\mathrm{pH}$ and EC parameters of sediment were measured by 1:10 sediment-water mixture using a Hach Brand Sension 156 device. Organic matter content percentages were measured using the incineration method [7]. TN was extracted by wet digestion with a mixture of nitric acid and sulfuric acid, and then measured using the vapor distillation method [8]. TP were measured by the ascorbic acid method [6].

For determining total $\mathrm{Cr}$ and $\mathrm{Ni}$ concentrations, homogenized sediment samples were digested with aqua regia solution $3 / 1(\mathrm{v} / \mathrm{v}) \mathrm{HCl} / \mathrm{HNO}_{3}$ in a microwave device and then diluted to $50 \mathrm{ml}$ with mili-Q water. Samples were placed in Teflon cups and digestion operations were performed in a CEM brand Mars 5 microwave device [2]. For analysis of different chemical fractions of heavy metals, $2 \mathrm{~g}$ fresh sediment portions were placed into $50 \mathrm{ml}$ polycarbonate centrifuge tubes, and were sequentially extracted as per the scheme given by Zeien and Brümmer [9] to obtain the following five operationally defined fractions of heavy metals:

- F1 (mobile): one extraction with $1 \mathrm{M} \mathrm{NH}_{4} \mathrm{NO}_{3}$.

- F2 (easily mobilizable): one extraction with $1 \mathrm{M}$ $\mathrm{CH}_{3} \mathrm{COONH}_{4}(\mathrm{pH} 6)$.

- F3 (bound to Mn oxide): one extraction with $0.1 \mathrm{M}$ $\mathrm{NH}_{2} \mathrm{OH}-\mathrm{HCl}+1 \mathrm{M} \mathrm{CH} \mathrm{COONH}_{4}(\mathrm{pH}$ 6) and two extractions with $1 \mathrm{M} \mathrm{CH}_{3} \mathrm{COONH}_{4}(\mathrm{pH}$ 6).

- F4 (bound to organic matter): one extraction with $0.025 \mathrm{M} \mathrm{NH}_{4}$-EDTA (pH 4.6) and two extractions with $1 \mathrm{M} \mathrm{CH}_{3} \mathrm{COONH}_{4}(\mathrm{pH} 4.6)$.

- F5 (residual and bound to Fe-oxide): were determined by calculating the difference between the total metal concentrations and the sum of concentrations of four fractions [9].
Heavy metals in water and sediment were determined using the VISTA-MPX model of the VARIAN brand ICPOES device. The relationships between water quality parameters with $\mathrm{Cr}-\mathrm{Ni}$ fractions were performed using the SPSS 22.0 statistical program. Correlation coefficients ( $r$ values) determined the correlations between parameters, and $p$ values showed the significance levels. The significance level was detected as $\mathrm{p}=0.05$.

\section{Results and Discussion}

Physicochemical Properties and Heavy Metals
in Water

After one year of monitoring processes, seasonal values of water quality parameters are given in Table 1 . $\mathrm{T}$, TN, and TP showed maximum values during summer, while minimum values were recorded during autumn. The nutrient concentrations in the lake are dependent on nutrient loads coming from internal and external sources, sedimentation, flow rates of the rivers that recharge to and discharge from the lake, and phytoplankton nutrient consumption [10]. Also, agricultural activities in the region start in the same seasons, so the transport of nitrogen forms from agricultural areas into the lake increase in summer [11]. High alkalinity is observed in the water bodies with eutrophication, particularly during spring. Furthermore, the high alkalinity of lake water might be due to the use of detergents and washoff from areas with calcite and dolomite [12]. In spring months as microbial activities increase, the degradation rate of the organic matters increases. Therefore, the DO level decreases when $\mathrm{BOD}_{5}$ and $\mathrm{COD}$ increase. DO and SS

Table 1. Seasonal and statistical variation of water quality parameters in Uluabat Lake.

\begin{tabular}{|c|c|c|c|c|c|c|c|}
\hline Parameter & $\mathrm{N}$ & Mean $\pm \mathrm{SD}$ & Max-Min & Summer & Autumn & Winter & Spring \\
\hline Alkalinity $\left(\mathrm{mg} \mathrm{CaCO}_{3} / \mathrm{l}\right)$ & 12 & $238.4 \pm 17.0$ & $285-193$ & 235.3 & 234.4 & 227.6 & 256.4 \\
\hline $\mathrm{BOD}_{5}(\mathrm{mg} / \mathrm{l})$ & 12 & $23.3 \pm 11.3$ & $50-5$ & 26.9 & 25.5 & 12.6 & 28.2 \\
\hline $\mathrm{COD}(\mathrm{mg} / \mathrm{l})$ & 12 & $71.9 \pm 41.6$ & $192-16$ & 78.9 & 110.8 & 36.7 & 61.3 \\
\hline $\mathrm{DO}(\mathrm{mg} / \mathrm{l})$ & 12 & $10.1 \pm 1.05$ & $12.3-7.3$ & 9.1 & 9.6 & 11.1 & 10.5 \\
\hline $\mathrm{EC}(\mu \mathrm{s} / \mathrm{cm})$ & 12 & $628.4 \pm 37.9$ & $766-530$ & 597.9 & 641.6 & 641.1 & 632.8 \\
\hline $\mathrm{pH}$ & 12 & $8.5 \pm 0.17$ & $9.1-8.1$ & 8.52 & 8.62 & 8.55 & 8.46 \\
\hline $\mathrm{SS}(\mathrm{mg} / \mathrm{l})$ & 12 & $29.0 \pm 19.9$ & $92-4$ & 31.2 & 28.2 & 35.0 & 21.6 \\
\hline $\mathrm{T}\left({ }^{\circ} \mathrm{C}\right)$ & 12 & $16.3 \pm 6.3$ & $26.4-5.8$ & 22.3 & 17.4 & 9.02 & 14.1 \\
\hline $\mathrm{TN}(\mathrm{mg} / \mathrm{l})$ & 12 & $14.5 \pm 4.6$ & $32.9-8.4$ & 18.1 & 15.0 & 13.2 & 11.5 \\
\hline $\mathrm{TP}(\mu \mathrm{g} / \mathrm{l})$ & 12 & $61.8 \pm 15.2$ & $131.7-38.7$ & 77.5 & 64.1 & 51.6 & 54.2 \\
\hline $\mathrm{Cr}($ dissolved $)(\mathrm{mg} / \mathrm{l})$ & 12 & $0.022 \pm 0.03$ & $0.249-0.0$ & 0.019 & 0.031 & 0.021 & 0.017 \\
\hline $\mathrm{Ni}($ dissolved $)(\mathrm{mg} / \mathrm{l})$ & 12 & $0.012 \pm 0.01$ & $0.091-0.0$ & 0.013 & 0.012 & 0.017 & 0.007 \\
\hline $\mathrm{Cr}(\mathrm{particulate})(\mathrm{mg} / \mathrm{kg})$ & 12 & $10.53 \pm 8.5$ & $42.2-0.95$ & 11.94 & 8.51 & 14.62 & 7.05 \\
\hline $\mathrm{Ni}(\mathrm{particulate})(\mathrm{mg} / \mathrm{kg})$ & 12 & $20.77 \pm 32.1$ & $159.3-1.2$ & 14.78 & 11.71 & 49.51 & 7.10 \\
\hline
\end{tabular}

$\mathrm{N}$ number of samples, SD standard deviation, Max maximum, Min minimum 
concentrations showed maximum during winter, while minimum values were recorded in summer and in spring. When rainfall intensity and wind speed increase in spring and winter, circulation happens in the lake and thus the flow rates recharging the lake increase, and as a result of these mixings the lake water gains oxygen again. In addition, as dilution increases, the concentrations of the organic pollutants decrease [12]. SS concentrations are higher both in winter and summer seasons. Uluabat Lake and its surroundings are windy in summer and the fluxes and waves formed at that time cause an aeration in the sediment layer at the bottom so that solids are re-suspended in the water due to the lower water depth. When the algae increase in summer, the SS concentration increase is seen to be associated with this [13]. In winter, flows coming from the basin cause an increase in concentrations [14]. Significant amounts of organic pollutants and suspended solids transported with MKP Brook have been reported by Aksoy and Özsoy (2002).

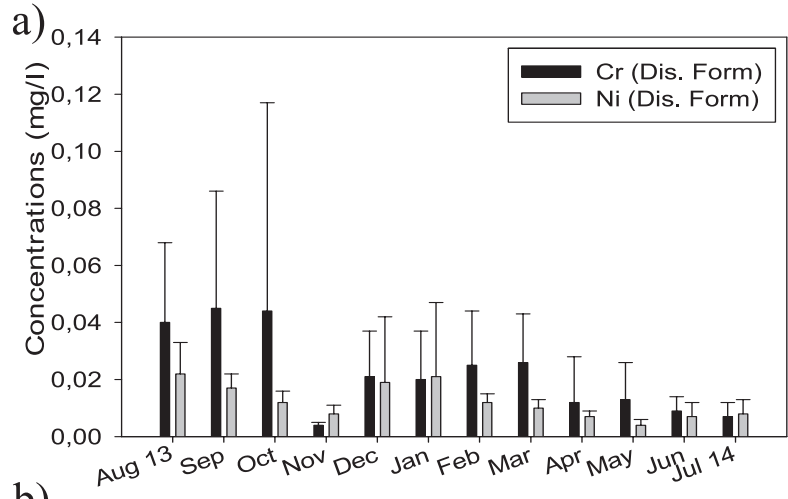

b)

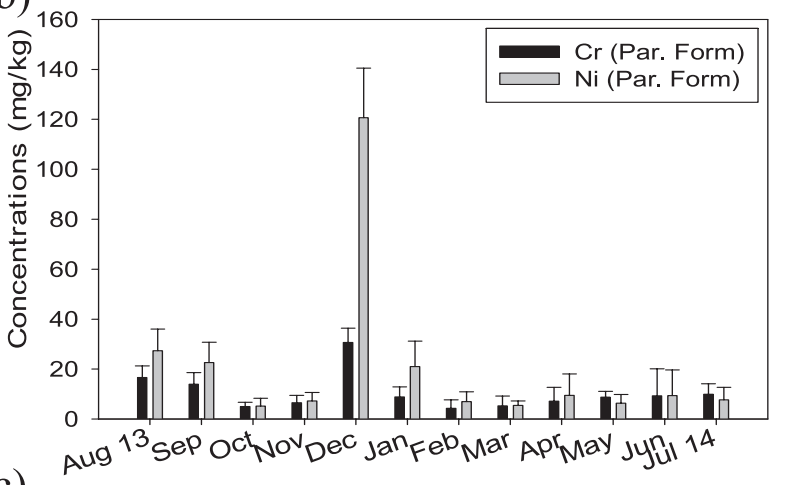

c)

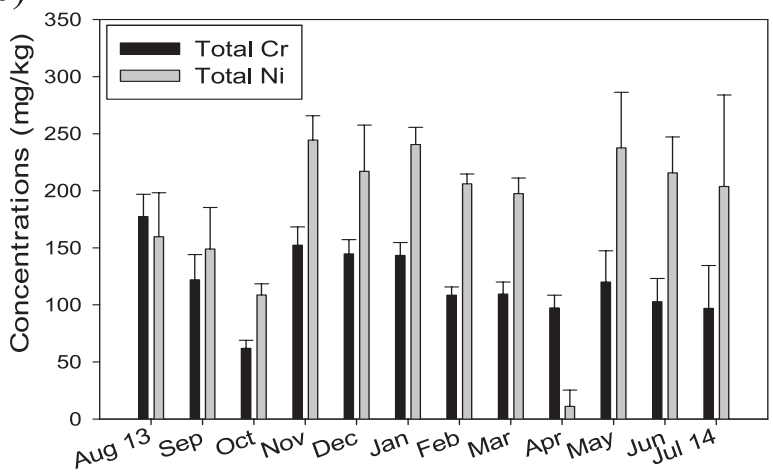

Fig. 2. Monthly variations of a) dissolved, b) particulate, and c) sediment forms of metals.
Heavy metal pollution is currently of major environmental concern. $\mathrm{Cr}$ and $\mathrm{Ni}$ are toxic and carcinogenic. There are different forms of these metals in water and sediment. High levels of these metals accumulate in aquatic environments. Previously, metal measurement studies were analyzed. There are important chromium and nickel enterprises in the lake basin. This situation contributes to the pollution load of heavy metals $(\mathrm{Cr}, \mathrm{Ni})$ from the lake. It is thought that the two metals are important for the lake and should be investigated. For these reasons, these metals were assessed in this study. Seasonal variations and some statistical values of $\mathrm{Cr}$ and $\mathrm{Ni}$ concentrations in dissolved form and particulate form of lake water are presented in Table 1. Monthly variations of $\mathrm{Cr}-\mathrm{Ni}$ forms are presented in Fig. 2.

When the monthly variations of dissolved and particulate forms of metals were examined, generally $\mathrm{Cr}$ and $\mathrm{Ni}$ concentrations were maximum during autumn and winter months, while minimum concentrations were observed during spring months. This trend could be due to precipitation and runoff from the lake basin area during the rainy season. Due to seasonal changes, factors such as wind speed and precipitation, suspended solids, conductivity, salinity, $\mathrm{pH}$, temperature, and organic substance concentration affect heavy metal concentrations in water and sediment [15]. Heavy metals are important constituents of the environment and their inputs always result in the deterioration of the aquatic environment [16]. Most studies have reported that $\mathrm{Cu}, \mathrm{Cr}, \mathrm{Co}$, and $\mathrm{Ni}$ can originate primarily from industrial and urban activities such as electrical machinery operation, chemical production, automobile exhaust, and mining [1, 12, 15-17].

\section{Physicochemical Properties and Heavy Metals in Sediment}

The physicochemical parameters of sediment samples are presented in Table 2, which shows that $\mathrm{pH}$ ranged from 8.98 to 7.3 . The $\mathrm{pH}$ of sediment gives an overview chemical status of the surface layer [18]. EC ranged from 368.4 to $284.9 \mu \mathrm{s} / \mathrm{cm}$. The percentage of organic matter refers to the accumulation load of organic matter transported from the lake to sediment. The load of organic matter is usually a result of domestic wastewaters and agricultural activities. It is also estimated that the nitrogen and phosphorus forms observed in the sediment layer originated due to domestic discharges and agricultural activities.

Monthly variations of total forms of $\mathrm{Cr}$ and $\mathrm{Ni}$ in sediment are presented in Fig. 2. Industrial and agricultural activities that occur in the basin have significant effects on lake pollution with superficial flow. In addition, Turkey's most important mines and ore enterprises such as boron, lignite, colemanite, and chrome operations take place in the basin. This situation contributes to the pollution load of heavy metals (Cr, B, Ni) of the lake [17]. A number of studies on the metal distribution in lake sediments have been performed [17, 19-22]. It was observed that metals in the sediment of Lake Uluabat had similar concentration values compared to the Karataş shallow lake study 
Table 2. Seasonal and statistical variation of sediment quality parameters in Uluabat Lake.

\begin{tabular}{|c|c|c|c|c|c|c|c|}
\hline Parameter & $\mathrm{N}$ & Mean \pm SD & Max-Min & Summer & Autumn & Winter & Spring \\
\hline $\mathrm{pH}$ & 12 & $8.3 \pm 0.35$ & $8.98-7.3$ & 8.4 & 7.9 & 8.4 & 8.5 \\
\hline $\mathrm{EC}(\mu \mathrm{s} / \mathrm{cm})$ & 12 & $319.6 \pm 67.43$ & $601-219$ & 368.4 & 322.8 & 284.9 & 302.5 \\
\hline Organic Matter $(\%)$ & 12 & $3.7 \pm 0.49$ & $4.66-2.11$ & 3.9 & 3.7 & 3.4 & 3.7 \\
\hline $\mathrm{TN}(\mathrm{mg} / \mathrm{kg})$ & 12 & $3302.8 \pm 1697.9$ & $8260-700$ & 4690 & 4246.6 & 1960 & 2314.6 \\
\hline $\mathrm{TP}(\mathrm{mg} / \mathrm{kg})$ & 12 & $330.6 \pm 288.7$ & $1233.6-11.5$ & 336.5 & 57.3 & 357.4 & 571.1 \\
\hline$\Sigma \mathrm{Cr}(\mathrm{mg} / \mathrm{kg})$ & 12 & $119.74 \pm 34.70$ & $210.52-1.02$ & 125.7 & 112.1 & 132.1 & 108.9 \\
\hline$\Sigma \mathrm{Ni}(\mathrm{mg} / \mathrm{kg})$ & 12 & $196.27 \pm 52.32$ & $310.28-2.05$ & 193.0 & 167.3 & 221.2 & 203.4 \\
\hline
\end{tabular}

$N$ number of samples, $S D$ standard deviation, Max maximum, Min minimum

performed by Başyiğit and Özan. They found mean $\mathrm{Cr}$ concentrations of $53.13 \mathrm{mg} / \mathrm{kg}$ and $\mathrm{Ni}$ concentrations of $203.92 \mathrm{mg} / \mathrm{kg}$ in Karataş Lake sediment.

The degree of contamination from the heavy metals could be assessed by determining the geoaccumulation index (Igeo), which has been widely applied for assessing sediment contamination. In order to characterize the level of pollution in the sediment, geoaccumulation index (Igeo) values were calculated using equation (1):

$$
\mathrm{I}_{\mathrm{geo}}=\log _{2}[\mathrm{Cn} /(1.5 \times \mathrm{Bn})]
$$

...where $\mathrm{Cn}$ is the measured concentration of metal $\mathrm{n}$ in the sediment and $\mathrm{Bn}$ is the geochemical background value of element $\mathrm{n}$ in the background sample [23].

In this study, Bn was used according to Turekian and Wedepohl (1961) geochemical background values used in the clay marine sediment (Table 3 ). The factor 1.5 is introduced to minimize the possible variations in the background values, which may be attributed to lithogenic effects. Igeo values were interpreted as Igeo $\leq 0$ : practically uncontaminated; $0 \leq$ Ige $0 \leq 1$ : uncontaminated to moderately contaminated; $1 \leq$ Igeo $\leq 2$ : moderately contaminated; $2 \leq$ Igeo $\leq 3$ : moderately to heavily contaminated; $3 \leq$ Igeo $\leq 4$ : heavily contaminated; $4 \leq$ Igeo $\leq 5$ : heavily to extremely

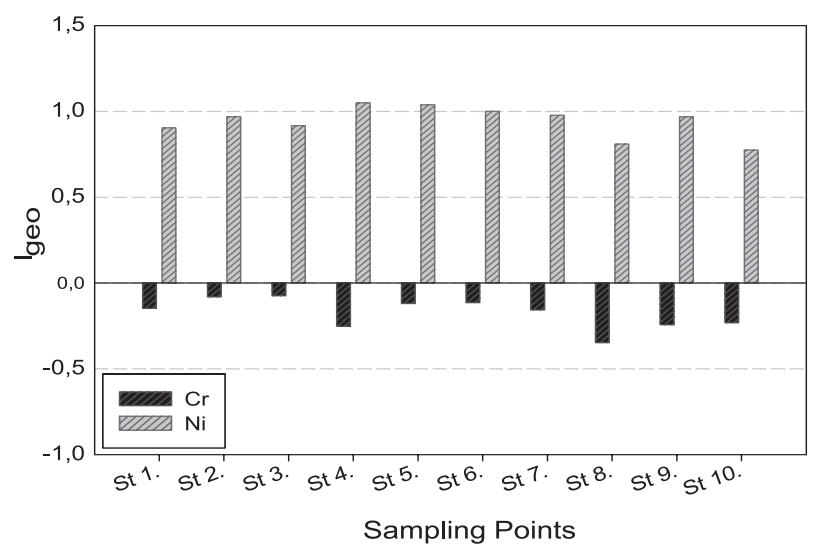

Fig. 3. Index of geoaccumulation (Igeo) values of measured heavy metals in Lake Uluabat sediments. contaminated; and 5<Igeo: extremely contaminated [2425].

The calculated Igeo of the investigated heavy metals in the sediments of Lake Uluabat and its corresponding contamination intensity are illustrated in Fig. 3, which shows that the highest Igeo value was obtained for $\mathrm{Ni}$ and the lowest for Cr. According to the geoaccumulation scale, the Igeo values for $\mathrm{Ni}$ indicate moderately polluted sediment while the $\mathrm{Cr}$ Igeo values indicate practically uncontaminated sediment. Ren et al. (2015) reported that the degree of pollution in sediments could be assessed by determining the indices such as the geo-accumulation index. The calculated Igeo results indicated that only $\mathrm{Cr}$ (0.57) could be considered unpolluted to moderately polluted at some of the study stations. All other metals showed an unpolluted situation for other stations in Yellow River surface sediment. In total, the pollution class from the Qinghai section upstream of the Yellow was 0-1 (unpolluted to moderately polluted) [26]. Islam et al. (2015) found the Igeo values in the order of the Korotoa River of Bogra sediment as $\mathrm{Cd}>\mathrm{As}>\mathrm{Pb}>\mathrm{Cu}>\mathrm{Ni}>\mathrm{Cr}$. Among the sites, the range of Igeo values indicates unpolluted to moderately polluted status of the sediment [24].

Sediment quality guidelines are important tools for assessing contamination in marine and estuarine sediments with biological significance [27]. Although such guidelines are not definitive indicators of toxicology, they can have a high predictive ability and are vital tools for identifying areas with potential adverse biological effects [28]. Concentrations of studied metals in Lake Uluabat sediment, geochemical background, and the toxicological reference values for sediments are given in Table 3. These values were used for calculating Igeo values. Also, the results were evaluated in comparison with U.S. National Oceanic and Atmospheric Administration, U.S. Environmental Protection Agency, and interim sediment quality guideline regulations. As a result, $\mathrm{Cr}$ and $\mathrm{Ni}$ values were defined above some toxic levels according to the guidelines. These metals were determined to be higher than upper effect threshold (UET) concentrations, except ISQG $\mathrm{I}_{\text {high }}$ $\mathrm{Cr}$ value. We observed that these metals in the Uluabat sediment had similar concentrations compared to the other 
Table 3. Concentrations of metals in Lake Uluabat sediment, geochemical background, and the toxicological reference values for sediments ( $\mathrm{mg} / \mathrm{kg}$ dry weight).

\begin{tabular}{|c|c|c|c|c|c|c|c|c|c|}
\hline \multirow{2}{*}{ Metal } & \multirow{2}{*}{ This study } & \multicolumn{2}{|c|}{ Geochemical Background } & \multicolumn{3}{|c|}{ NOAA $^{\mathrm{c}}$} & US EPA $^{\mathrm{d}}$ & \multicolumn{3}{c|}{ ISQG $^{\mathrm{e}}$} \\
\cline { 3 - 11 } & & Shale standard & Earth crust & TEL & PEL & UET & & ISQG $_{\text {low }}$ & ISQG $_{\text {high }}$ \\
\hline $\mathrm{Cr}$ & 119.7 & 90 & 100 & 37.3 & 90 & 95 & 26 & 80 & 370 \\
\hline $\mathrm{Ni}$ & 196.2 & 68 & 75 & 18 & 35.9 & 43 & 16 & 21 & 52 \\
\hline
\end{tabular}

Note: TEL Threshold effect level; PEL Probable effect level; UET Upper effect threshold; ISQG Interim sediment quality guideline;

US EPA: U.S. Environmental Protection Agency; NOAA: U.S. National Oceanic and Atmospheric Administration.

a $[42],{ }^{\mathrm{b}}[43],{ }^{\mathrm{c}}[44],{ }^{\mathrm{d}}[45],{ }^{\mathrm{e}}[46]$

lakes [28-32]. The concentrations of the metals $\mathrm{Cr}, \mathrm{Pb}$, and Ni in soils from the Southern Marmara Region, where tomatoes are cultivated on an industrial scale, were found to exceed the relevant limits. It is possible that these heavy metals accumulate in the sediment after reaching the lake via surface flows from the basins of MKP Brook and Lake Uluabat, where agronomic practices are intensively applied. Moreover, the high content of $\mathrm{Ni}$ is thought to originate from the structure of the soil itself [33].

\section{Chemical Fractions of Heavy Metals in Sediments of Lake Uluabat}

Heavy metals exist in sediments in a number of chemical forms, and generally exhibit different physical and chemical behaviors in terms of chemical interaction, mobility, biological availability, and potential toxicity [34-
35]. These chemical fractions are: exchangeable (soluble species, cation exchange sites, and bound to carbonates), reducible (bound to Fe and $\mathrm{Mn}$ oxides), oxidizable (bound to organic matter and sulphides), and residual (bound to the mineral matrix) [9]. There is abundant evidence showing that the translocation ability is indicated by the total content of exchangeable heavy metals, and the bioavailability of the heavy metals is the sum of the concentrations of the exchangeable, reducible, and oxidizable heavy metals fractions, while the residual metals are mainly not available [36]. Most of the previous studies have been limited only to the determination of the total concentrations of metals in sediments, which is a poor indicator and reflects only the maximum amount of contamination when the metal properties basically depend on their binding state, sediment properties like $\mathrm{pH}, \mathrm{EC}$, total organic carbon (TOC), redox conditions and their chemical spe-
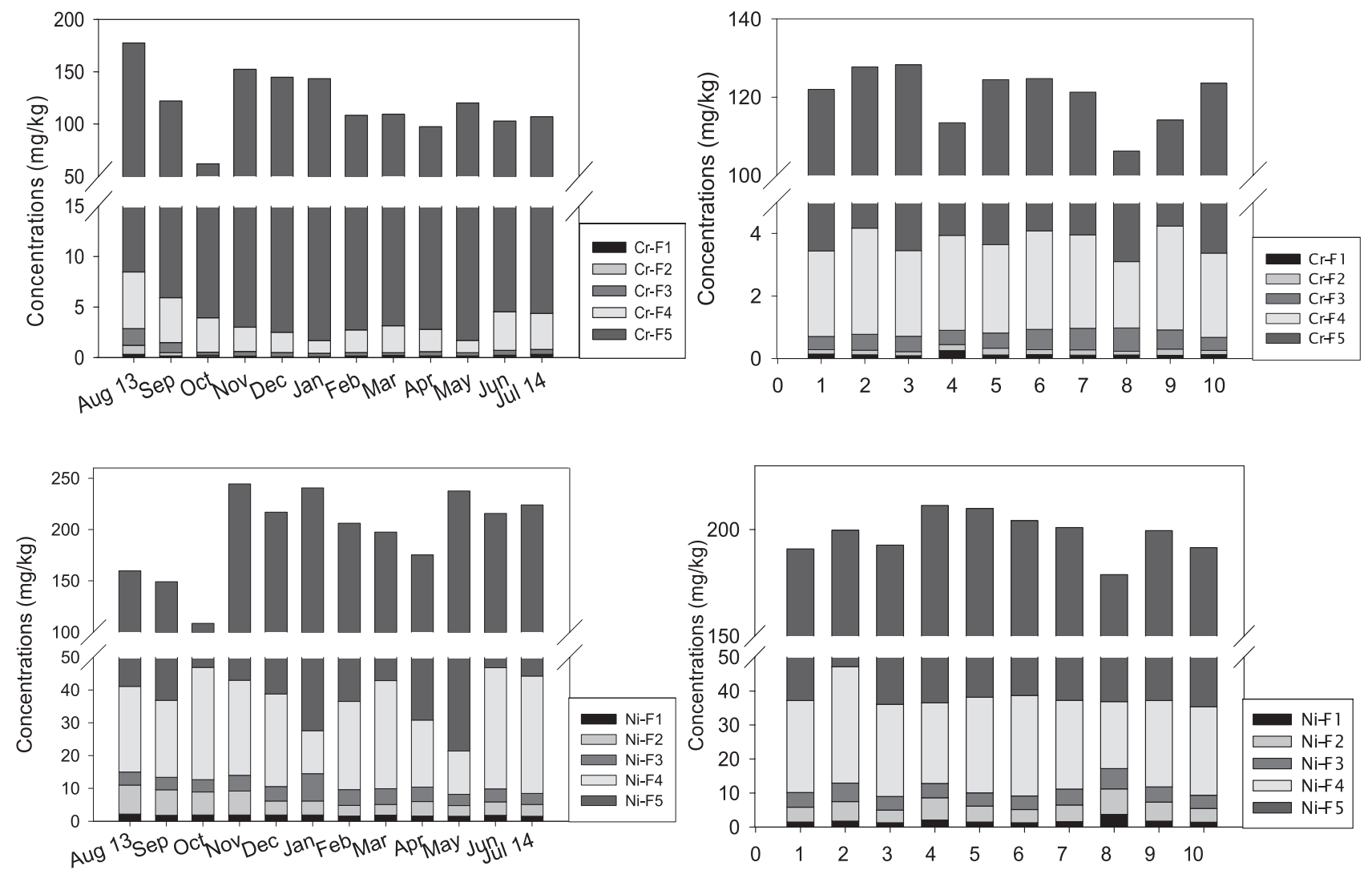

Fig. 4. Temporal and spatial variations of the fractions of $\mathrm{Cr}-\mathrm{Ni}$ according to months and stations. 
Table 4. Relationship between physicochemical properties of Lake Uluabat and concentrations of heavy metals.

\begin{tabular}{|c|c|c|c|c|c|c|}
\hline & Cr dissolved & Cr particulate & Cr sediment & Ni dissolved & Ni particulate & Ni sediment \\
\hline T & $0.408^{*}$ & 0.093 & -0.078 & 0.102 & -0.095 & 0.007 \\
\hline $\mathrm{pH}$ & $0.381^{*}$ & -0.145 & $0.376^{*}$ & $0.595^{*}$ & -0.058 & $0.363^{*}$ \\
\hline $\mathrm{EC}$ & $0.383^{*}$ & $-0.232^{*}$ & 0.109 & $0.477^{*}$ & $0.279^{*}$ & $0.220^{*}$ \\
\hline DO & $-0.283^{*}$ & -0.036 & 0.162 & $-0.524^{*}$ & -0.071 & 0.146 \\
\hline Alkalinity & $0.356^{*}$ & 0.099 & -0.028 & $0.572^{*}$ & 0.020 & -0.056 \\
\hline SS & $0.235^{*}$ & $0.458^{*}$ & $0.580^{*}$ & 0.174 & $0.509^{*}$ & $0.481^{*}$ \\
\hline TN & $0.312^{*}$ & $0.256^{*}$ & 0.074 & $0.273^{*}$ & $0.239^{*}$ & 0.113 \\
\hline TP & 0.067 & 0.118 & 0.061 & 0.102 & $0.316^{*}$ & 0.072 \\
\hline COD & $0.326^{*}$ & $0.283^{*}$ & 0.056 & $0.648^{*}$ & $0.580^{*}$ & 0.034 \\
\hline
\end{tabular}

*Significant at p - 0.05 level

All cells show the correlation coefficient (r)

ciation [37]. In this study, chemical fractions of $\mathrm{Cr}$ and $\mathrm{Ni}$ were determined. Variations in the annual averages of these fractions according to months and stations are presented in Fig. 4.

According to Fig. 4, it is obviously that the distribution patterns of heavy metals in sediments differ greatly due to the various factors. These metals have an appreciable portion in residual fraction in all sedimentary samples. This situation reflects that metals have the strongest association with the crystalline structures of the minerals and they are stable under natural conditions with lower transfer ability [4]. In October, with the start of precipitation, concentrations of metals decrease due to dilution. Also, it was seen that metal concentrations in sediment were low at station 8. This station, which is a stagnant region, is far from the input and output points of the lake. Therefore, pollution in the station has been observed to be less intense. It was observed that the residual and bound to Fe-oxide fraction (F5) of $\mathrm{Cr}$ and $\mathrm{Ni}$ were the most dominant fraction in the lake sediment. $\mathrm{Cr}$ can potentially hazard the surrounding environments due to the fact that it is a highly toxic metal, which has been linked to cancer in humans following prolonged inhalation, and is toxic to aquatic life at relatively low concentrations [38]. Katip et al. (2012) found that the residual fraction is the most dominant form of $\mathrm{Ni}$ with a percentage of $98.97 \%$ [15]. Next to residual fraction, the second most dominant fraction was organically bound (Ni-F4) fraction as $13.58 \%$. (Ni-F2) was the third most common fraction at $2.58 \%$. Bound to Mn-oxides (Ni-F3) was found at a percentage of $2.28 \%$ - the fourth most common fraction. It is well known that $\mathrm{Mn}$ oxides retain nickel in the sediment [12]. The lowest fraction of nickel was Ni-F1, at $0.90 \%$. Ni can be raised from natural rocks as well as anthropogenic sources. Relatively higher percentages of $\mathrm{Ni}$ in residual fraction obtained, has indicated that an appreciable percentage of $\mathrm{Ni}$ is likely to be incorporated in aluminosilicate minerals and it is relatively insensitive to the change of surrounding conditions. The little portion of $\mathrm{Ni}$ in exchangeable fraction may be a result of combustion of fuel, especially along highways [39]. Ma et al. (2016) found that $\mathrm{Cr}$ is mainly associated to the residual fraction $(65.70 \%-86.38 \%)$, and the amounts of $\mathrm{Cr}$ in the exchangeable and oxidizable fractions ranged from $2.38 \%$ to $22.13 \%$ and $7.94 \%-18.79 \%$, respectively. Only less than $3 \%$ of $\mathrm{Cr}$ has been found in reducible fraction [4]. Singh et al. (2008) indicated that the residual (Ni-F5) fraction of Ni represented the most dominant fraction and it accounted for 33.98 to $63.66 \%$ of total $\mathrm{Ni}$ in lake sediments. Next to residual fraction, the second most dominant fraction was organically bound (Ni-F3) fraction, which represented 12.52 to $25.55 \%$ of total Ni. Carbonate bound (Ni-F2) fraction was the third most dominant fraction of $\mathrm{Ni}$ (representing 13.94 to $29.64 \%$ of total $\mathrm{Ni}$ ). Iron and manganese oxide-bound (Ni-F4) fraction accounted for 7.28 to $11.49 \%$ total Ni. Water soluble + exchangeable (Ni-F1) fraction represented the least dominant fraction of $\mathrm{Ni}$ and accounted for an average of $4.81 \%$ of total $\mathrm{Ni}$ [12].

\section{Relationships between Physicochemical Properties of Lake Water and Heavy Metals Concentrations}

The results have been evaluated with a statistical test. These tests were carried out using the SPSS 22.0 program. Simple correlation coefficients (r) computed between physicochemical properties and concentrations of different heavy metals formed in Uluabat Lake are presented in Table 4.

The concentration of $\mathrm{Cr}$ in dissolved form was significantly and positively correlated with $\mathrm{T}, \mathrm{pH}, \mathrm{EC}$, Alkalinity, SS, TN, and COD of water at $p=0.05$. Crdis was significantly and negatively correlated with DO. The concentration of $\mathrm{Cr}$ in particulate form was significantly and positively correlated with SS, TN, TP, and COD of water at $p=0.05$. Furthermore, Crpar was significantly and negatively correlated with EC. The concentration of $\mathrm{Cr}$ in sediment total form was significantly and positively correlated with $\mathrm{pH}$, and $\mathrm{SS}$ of water at $\mathrm{p}=0.05$. The concentration of $\mathrm{Ni}$ in dissolved form was significantly 
Table 5. Relationship between metal concentrations in waters with different chemical fractions of metals in sediments.

\begin{tabular}{|c|c|c|c|c|c|c|}
\hline & $\begin{array}{c}\text { Mobile } \\
(\mathrm{F} 1)\end{array}$ & $\begin{array}{c}\text { Easily mobilizable } \\
(\mathrm{F} 2)\end{array}$ & $\begin{array}{c}\text { Bound to Mn-oxide } \\
(\mathrm{F} 3)\end{array}$ & $\begin{array}{c}\text { Bound to Organic Matter } \\
\text { (F4) }\end{array}$ & $\begin{array}{c}\text { Residual } \\
\text { (F5) }\end{array}$ & $\begin{array}{c}\text { Total } \\
\text { Sediment }\end{array}$ \\
\hline Cr dissolved & $0.242^{*}$ & 0.085 & 0.063 & $0.308^{*}$ & 0.081 & 0.084 \\
\hline Cr particulate & 0.103 & 0.106 & -0.059 & $0.314^{*}$ & $0.637^{*}$ & 0.152 \\
\hline Ni dissolved & $0.682^{*}$ & 0.040 & 0.186 & 0.106 & 0.098 & 0.103 \\
\hline Ni particulate & 0.024 & 0.068 & $0.257^{*}$ & $0.273^{*}$ & 0.121 & 0.054 \\
\hline
\end{tabular}

*Significant at $\mathrm{p}-0.05$ level

All cells show the correlation coefficient (r)

and positively correlated with $\mathrm{pH}, \mathrm{EC}$, Alkalinity, TN, and COD of water at $\mathrm{p}=0.05$. Also, this form was significantly and negatively correlated with DO. The concentration of $\mathrm{Ni}$ in particulate form was significantly and positively correlated with EC, SS, TN, TP, and COD of water at $\mathrm{p}=0.05$. The concentration of $\mathrm{Ni}$ in sediment total form was significantly and positively correlated with $\mathrm{pH}, \mathrm{EC}$, and SS of water.

The concentration of suspended solids in the water, temperature, $\mathrm{pH}$, electrical conductivity, total nitrogen, and total phosphorus have an effect on metal concentrations in water and sediment. The major factors that affect the biosorption processes are initial metal ion concentrations, temperature, $\mathrm{pH}$, and biomass concentration in solution [40]. $\mathrm{pH}$ is very important for mobility because metal availability is relatively low when $\mathrm{pH}$ is around 6.5 to 7 . The absorbed trace metals can be released again with the change of $\mathrm{pH}$ in the water. The metal removal is associated with lower $\mathrm{pH}$ because high $\mathrm{pH}$ value promotes adsorption and precipitation, while low $\mathrm{pH}$ can actually weaken the strength of metal association and impede the retention of metals by sediments [4]. Organic compounds, frequently existing in considerable amounts in particle form, play an important role in heavy metal transformation. For example, in the sediment of some rivers or lakes, the heavy metal bound to organic matter generally takes up the largest fraction. In natural lakes, organic matter is mainly composed of humic and fulvic substances. The complexation reaction between heavy metals and organic complexants is usually recognized as the most important reaction pathway, and due to this reaction the speciation and bioavailability of metals like the mobility of trace metals in natural water environment can be influenced [41]. Except for $\mathrm{pH}$ and organic matter, some other factors such as temperature, salinity, metal species, oxidation-reduction potential, and retention time can also affect the distributions of heavy metal in sediment. For example, their mobility capacity varies correspondingly due to the differences of cation exchange capacity among different metals. The adsorption content of heavy metals on sediment often decreases gradually with increasing temperature, with increasing salinity, and with increasing electrical conductivity. The total adsorption content of heavy metal would decrease ascribed to the competition among heavy metals and some other cations [15].
Chemical fractionation differentiates metals of natural origin and is derived from anthropogenic sources. Metal fractionation is of critical importance to their potential toxicity and mobility. The sequential extraction technique is proposed for this purpose to provide information about the strength and ways of metals associating with sediments [24]. The relationships between the metal concentrations in water and the chemical fractions in sediment have a meaning of the condition of the dynamic equilibrium of the elements in the sediment transfer into the water directly or indirectly. The fractions of the elements in the sediment that are mobile or easily mobilizable stand for the elements ready to be released into the water. Correlation coefficients ( $r$ ) computed between the concentrations of metal in waters and their different chemical fractions in sediment of Lake Uluabat are presented in Table 5.

The concentration of $\mathrm{Cr}$ in the dissolved form of water was significantly and positively correlated with mobile (Cr-F1) and organically bound (Cr-F4) sediments at $\mathrm{p}=0.05$, respectively. The concentration of $\mathrm{Cr}$ in the particulate form of water was significantly and positively correlated with organically bound (Cr-F4) and residual (Cr-F5) fractions of the sediments. The concentration of $\mathrm{Ni}$ in the dissolved form of water was significantly and positively correlated with mobile fraction (Ni-F1) of the sediments at $\mathrm{p}=0.05$. The concentration of $\mathrm{Ni}$ in the particulate form of water was significantly and positively correlated with bound to Mn-oxide (Ni-F3) and organically bound ( $\mathrm{Cr}-\mathrm{F} 4)$ fractions of the sediments at $\mathrm{p}=0.05$. The relationships between the concentrations of $\mathrm{Cr}$ in water with the bound to organic fraction in sediment were found to be significant. It is known that this metal forms organometallic complexes together with organic substances. Therefore, it was considered that this metal could become free as a consequence of turbulence or microbial decomposition, depending on the present physicochemical conditions and the equilibrium constants $[12,15]$.

The relationships between $\mathrm{Cr}$ and $\mathrm{Ni}$ with residual and bound-to-Fe-oxide fraction were found to be insignificant. Residual fractions can hold these metals by combining with the minerals in the sediment with a lattice structure or by reacting with insoluble sulfates [15]. Similarly, the relationships between these metals with total sediment concentrations were found to be insignificant. This situation is more common at agricultural sites. Relationships are 
expected to be significant in waters where anoxic conditions are common [2]. The heavy metals were mainly of natural origin due to weathering and erosion [28]. The absence of strong correlation among metals suggests that the concentrations of these metals were not controlled by a single factor, but a combination of geochemical support phases and their mixed associations [22]. The results in this study indicated that most examined metals didn't have common sources and that they originated from various sources, and change in their behavior during transport was seen. These metals might have different anthropogenic as well as natural sources.

\section{Conclusions}

The concentrations of $\mathrm{Cr}$ and $\mathrm{Ni}$ forms (dissolved, particulate, total sediment, sediment fractions) and other water and sediment quality parameters were assessed monthly at 10 sampling points between August 2013 and July 2014. The results of the present study clearly demonstrated that the concentrations of water and sediment quality parameters undergo monthly changes. According to the geoaccumulation and pollution indexes for the studied metals, Lake Uluabat has moderately polluted sediment and $\mathrm{Cr}$ and $\mathrm{Ni}$ values were determined to be higher than upper effect threshold concentrations. According to variations of the fractions of $\mathrm{Cr}$ and $\mathrm{Ni}$, bound to organic matter, residual and bound to $\mathrm{Fe}$-oxide fractions were found to be the most dominant forms. Mostly, all forms of $\mathrm{Cr}$ and $\mathrm{Ni}$ were significantly and positively correlated with $\mathrm{pH}, \mathrm{EC}$, and SS.

From the results observed, there should be more effort to protect Lake Uluabat from pollution to reduce environmental risks. This study will hopefully contribute to the development of a lake pollution prevention strategy. The main topics that may be needed to be investigated are control of industrial and domestic discharge, regular observation of pollutants, and evaluating the effects of pollutants on the lake's ecosystem over the long term, coordinating the pollution source and preventing inflow of pollutants to the lake. In order to decrease the trace metal pollution in the water and sediment, point and diffuse sources must be reduced to some extent. Also, the use of excessive chemical fertilizer and pesticides in agricultural activities in the basin must be prevented.

\section{Acknowledgements}

This research was funded by the Scientific Research Foundation of Uludag University (Project No. OUAP(M)-2013/6).

\section{References}

1. ÖZŞEKER K., ERUZ C., CILIZ S., MANI F. Assessment of Heavy Metal Contribution and Associated Ecological Risk in the Coastal Zone Sediments of the Black Sea: Trabzon. Clean- Soil Air Water 42 (10), 1477, 2014.

2. NGUYEN H.L., LEERMAKERS M., OSÁN J., TÖRÖK S., BAEYENS W. Heavy metals in Lake Balaton: water column, suspended matter, sediment and biota. Science of the Total Environment, 340 (1-3), 213, 2005.

3. PRADITA S., PATTARATHOMRONGA M.S., PANUTRAKUL S. Arsenic Cadmium and Lead Concentrations in Sediment and Biota from Songkhla Lake: A Review. Procedia - Social and Behavioral Sciences 91, 573, 2010.

4. MA X., ZUO H., TIAN M., ZHANG L., MENG J., ZHOU X., MIN N., CHANG X., LIU Y. Assessment of heavy metals contamination in sediments from three adjacent regions of the Yellow River using metal chemical fractions and multivariate analysis techniques. Chemosphere 144, 264, 2016.

5. DALKIRAN N., KARACAOĞLU D., DERE S., SENTÜRK E., TORUNOĞLU T. Factors affecting the current status of a eutrophic shallow lake (Lake Uluabat, Turkey): Relationships between water physical and chemical variables. Chemistry and Ecology 22, 79, 2006.

6. APHA, AWWA. Standard Methods for the examination of water and wastewater. American Public Heallth Association. 20th Editionn. Washington DC. USA. 1998.

7. RADOJEVIC M., BASHKIN V.N. Practical environmental analysis UK: The Royal Society of Chemistry, Cambridge. 325, 1999.

8. KACAR B. Chemical Analysis of Plants and Soils III Soil Analysis. Ankara University of Agriculture Faculty Publications, Ankara, 1994.

9. ZEIEN H., BRÜMMER G.W. Chemische extraktionen zur bestimmung von schwermetallbindungs formen in böden. Mitteilgn Dtsch Badenkundl Gesellsch, 59, 505, 1989.

10. HEJZLAR J., VYHNALEK V. Longitudinal heterogeneity of phosphorus and phytoplankton concentrations in deepvalley reservoirs. International Review of Hydrobiology, 83, $139,1998$.

11. ELMACI A., TEKSOY A., TOPAÇ F.O., ÖZENGIN N., BAŞKAYA H.S. Monitoring Seasonal Variation of Microbiological Characteristics of Lake Uluabat. Uludag University Journal of the Faculty of Engineering and Architecture, 13 (1), 93-103, 2008.

12. SINGH A.P., SRIVASTAVA P.C., SRIVASTAVA P. Relationships of Heavy Metals in Natural Lake Waters with Physicochemical Characteristics of Waters and Different Chemical Fractions of Metals in Sediments. Water Air Soil Pollut. 188, $181,2008$.

13. STUMM W., MORGAN J. Aquatic Chemistry: An Introduction Emphasizing Chemical Equilibria in Natural Water, Wiley, New York, 1996.

14. AKSOY E., ÖZSOY G. Investigation of multi-temporal land use/cover and shoreline changes of the Uluabat Lake Ramsar site using RS and GIS. paper presented at the International Conference on Sustainable Land Use and Management Çanakkale, Turkey. 1, 13-22, 13 October 2002.

15. KATIP A., KARAER F., İLERİ S., SARMAŞIK S., AYDOĞAN N., ZENGINAY S. Analysis and assessment of trace elements pollution in sediments of Lake Uluabat, Turkey. Journal of Environmental Biology, 33, 961, 2012.

16. CAİ Y., ZHANG W., ZHOU M., JİANG H., XU D., AN S., LENG X. Comprehensive assessment of heavy metal contamination in surface sediments from the inflow rivers of Taihu Basin. Clean Soil Air Water, CSAWAC 43 (12) 1559, 2015. 
17. ELMACI A., TEKSOY A., TOPAC, F.O., ÖZENGIN N., KURTOĞLU S., BASKAYA H.S. Assessment of heavy metals in Lake Uluabat, Turkey. African Journal of Biotechnology, 6, 2236, 2007.

18. İLERİ S., KARAER F., KATIP A., ONUR, S. Evaluation of Water Quality in Shallow Lakes. Case Study of Lake Uluabat. Uludağ University Journal of The Faculty of Engineering 19 (1), 47, 2014.

19. KAZANCI N., LEROY S.A.G., ÖNCEL S., İLERİ O., TOPRAK O., COSTA P. Wind control on the accumulation of heavy metals in sediment of Lake Ulubat, Anatolia, Turkey. Journal of Paleolimnology, 43, 89, 2010.

20. BAŞYİĞIT B., TEKIN-ÖZAN S. Concentrations of Some Heavy Metals in Water, Sediment, and Tissues of Pikeperch (Sander lucioperca) from Karataş Lake Related to PhysicoChemical Parameters, Fish Size, and Seasons. Pol. J. Environ. Stud. 22 (3), 633, 2013.

21. CHEN L., CAİ Q., XU S., LIUU X., CHEN S. Distribution Characteristics, Pollution assessment, and Source identification of heavy metals in sediment of Wetlands Lakes. Pol. J. Environ. Stud. 24 (4), 1525, 2015.

22. DONG D., LIUU X., GUO Z., HUA X., SU Y., LİANG D. Seasonal and Spatial Variations of Heavy Metal Pollution in Water and Sediments of China's Tiaozi River. Pol. J. Environ. Stud. 24 (6), $2371,2015$.

23. İSLAM M.S., HAN S., MASUNAGA S. Assessment of trace metal contamination in water and sediment of some rivers in Bangladesh. J. Water Environ. Technol. 12, 109, 2014.

24. İSLAM M.S., AHMED M.K., RAKNUZZAMAN M., HABIBULLAH A.M.D., ISLAM M.K. Heavy metal pollution in surface water and sediment: A preliminary assessment of an urban river in a developing country. Ecological Indicators $48,282,2015$.

25. BOZSKE L., SOBCZYŃSKA T., GLOSIŃSKA G., KOW ALSKI A., SIEPAK J.Distribution of Mercury and other heavy metals in bottom sediments of the middle Odra river (Germany/Poland). Polish Journal of Environmental Studies 5: 495, 2004

26. REN J., SHANG Z., TAO L., WANG X. Multivariate Analysis and Heavy Metals Pollution Evaluation in Yellow River Surface Sediments. Pol. J. Environ. Stud. 24 (3), 1041, 2015.

27. HÜBNER R., ASTIN K.B., HERBERT J.H. Comparison of sediment quality guidelines (SQGs) for the assessment of metal contamination in marine and estuarine environments. J Environ Monit 11, 713, 2009.

28. BRAMHA S.N., MOHANTY A.K., SATPATHY K.K., KANAGASABAPATHY K.V., PANIGRAHİ S., SAMANTARA M.K., PRASAD M.V.R. Heavy metal content in the beach sediment with respect to contamination levels and sediment quality guidelines: a study at Kalpakkam coast, southeast coast of India. Environ Earth Sci 72, 4463, 2014.

29. AN Y., KAMPBELL D.H. Total dissolved and Bioavailable metals at Lake Texoma Marinas. Environ. Poll. 122, 253, 2003.

30. WOITKE P., WELLMITZ J., HELM D., KUBE P., LEPOM P., LITHERATY P. Analysis and assessment of the heavy metal pollution in suspended solids and sediments of the river Danube. Chemosphere, 51, 633, 2003.
31. KISHE M.A., MACHIWA F. Distribution of heavy metals in the sediments of Mwanza Gulf of lake Victoria, Tanzania. Environ. Int., 28, 619, 2003.

32. YIIĞITTERHAN O., MURRAY J.W. Trace metal composition of particulate matter of the Danube river and Turkish rivers draining into the Black Sea. Marine Chemistry, 111, 63, 2008.

33. BAŞAR H., GÜREL S., KATKAT A.V. Contents of heavy metals in the Lake İznik Basin soils irrigated with various water resources (in Turkish). Journal of Agricultural Faculty of Uludağ University, 18 (1), 93, 2004.

34. HALLI M., SARI E., KURT M.A. Assessment of Arsenic and Heavy Metal Pollution in Surface Sediments of the Ergene River, Turkey. Pol. J. Environ. Stud. 23 (5), 1581, 2014.

35. SUNDARAY S.K., NAYAK B.B., LIN S., BHATTA D. Geochemical speciation and risk assessment of heavy metals in the river estuarine sediments-a case study: Mahanadi basin, India. J. Hazard. Mater. 186, 1837, 2011.

36. VAROL M., Assessment of heavy metal contamination in sediments of the Tigris River (Turkey) using pollution indices and multivariate statistical techniques. J. Hazard. Mater. 195, 355, 2011.

37. NYAMANGARA J. Use of sequential extraction to evaluate zinc and copper in a soil amended with sewage sludge and inorganic metal salts. Agr. Ecosyst. Environ. 69, 135, 1998.

38. VENKATESWARAN P., VELLAICHAMY S., PALANIVELU K. Speciation of heavy metals in electroplating industry sludge and wastewater residue using inductively coupled plasma. Int. J. Environ. Sci. Technol. 4, 497, 2007.

39. NEMATI K., BAKAR N.K.A., ABAS M.R., SOBHANZADEH E. Speciation of heavy metals by modified BCR sequential extraction procedure in different depths of sediments fromSungai Buloh, Selangor, Malaysia. J. Hazard. Mater. 192, 402, 2011.

40. DAS N., VIMALA R., KARTHIKA P. Biosorption of heavy metals, An overview. Indian J. Biotechnol. 7, 159, 2008.

41. PENG J., YONG-HUI S., PENG Y., CUI X., GUANG-LEI Q. The remediation of heavy metals contaminated sediment. Journal of Hazardous Materials 161, 633, 2009.

42. TUREKIAN K.K., WEDEPOHL K.H. Distribution of the elements in some major units of the earth's crust. Geol. Soc. Am. Bull. 72, 175, 1961.

43. TAYLOR S.R. Abundances of chemical elements in the continental crust: a new table. Geochim. Cosmochim. Acta 28 (8), 1273, 1964

44. NOAA 1999. Screening Quick Reference Table for Inorganics in Solids, National Oceanic and Atmospheric Administration, Washington, 1999.

45. USEPA. Screening Level Ecological Risks Assessment Protocol for Hazardous Waste Combustion Facilities. Appendix E: Toxicity Reference Values. EPA 530-D99-001C, 3, http://www.epa.gov/epaoswer/hazwaste/combust/ eco-risk/ voume3/a ppx-e.pdf, 1999.

46. ISQG, Anzecc (Australian and New Zealand Environment and Conservation Council). Anzecc interim sediment quality guidelines. Report for the Environmental Research Institute of the Supervising Scientist. Sydney, Australia, 2000. 